\title{
ABILITY TO USE FLEXIBLE PROJECT MANAGEMENT IN THE HOTEL BUSINESS
}

\author{
Ardak Turginbayeva ${ }^{1,}$, , Gulmira Nurseitova ${ }^{1}$, Guldana Zhakupbekova $^{1}$, Kairat Doszhanov $^{2}$, \\ Aidar Konysbay ${ }^{3}$ \\ ${ }^{1}$ Al-Farabi KazNU, pr. al Farabi, 71, 050040 Almaty, Republic of Kazakhstan \\ ${ }^{2}$ International Educational Corporation, Almaty, Kazakhstan \\ ${ }^{3}$ University of International Business, Almaty, Republic of Kazakhstan
}

\begin{abstract}
The article discusses the possibilities of implementing flexible project management methods to ensure the effectiveness of projects in the hospitality industry. The Project Leader should encourage each participant to abandon his or her approved behavior model in order to promptly resolve any issues that may arise during the implementation of the project and to respond to internal objections. As the hotel business is customer-centric, providing end-to-end services is not possible through standard management of individual customer requirements. Therefore, this study aims to determine the feasibility of using the methodology by identifying several criteria for project management (APM) in the hotel business.
\end{abstract}

\section{Introduction}

While the tourism industry is an element of the economic system, the hotel business is an important part of the tourism industry. The development of the hotel business is a key precondition for tourism development, as the importance of promoting hospitality and service to incoming tourists to international standards. The issues of effective project management in this area are topical as successful implementation will lead to the development of the industry. There are many aspects that can lead to project effectiveness, and we have sought to make a comparative analysis of the methods used in project management in this study.

\section{Literature review}

There are various issues related to the volatility and uncertainty of the environment in the implementation of the Company's strategic goals. By identifying the potential and risks of the company, you can identify common issues. We can eliminate the uncertainty and systematize the issues by expanding the range of strategic issues we need to address the shortcomings of the existing structure of the company.

S.Ekberg (2019) argued that difficult-to-detect problems could occur if the members of the organization did not fully understand the implications of the issues. He believes that flexibility in the formulation of strategic questions should be used and that certain issues identified by identifying threats and opportunities should not be under-emphasized. The

\footnotetext{
*Corresponding author Ardak.Turginbayeva@kaznu.kz
} 
reason is that simple things that are not taken care of will hinder the success of the project. The three key success factors of a project - strict adherence to quality, deadline and time standards - had to take into account the variability of the environment, from planning to project management to the transfer to the customer, meaning that the traditional project management method did not produce the desired results in some project management. Then, in the early 2000's, the P2M standard was published, which describes the Japanese paradigm of project management (P2M, 2005). According to this standard, complexity is the key value for innovative projects. The more complicated your project management issues are, the more valuable it will be and only a few people on the project team will understand it, and the rest will be opposed. The project consists of interconnected and interdependent parts, each of which changes and each change affects the other, so the complexity criterion is important. However, complexity does not only describe the size, length, or number of parts of a particular system, but also that there are complex problems which are unknown for unknown reasons and cannot be solved immediately. According to Bar-Yam (2014), solving complex problems is not always easy. This required a flexible project management approach. The concept of Agile Manufacturing was introduced as a new paradigm in industry in the report 21st Century Manufacturing strategy: Industry Led-View and boosted the agile manufacturing movement in USA (Plonka, F. E., 1997). “ Agile is more a philosophy, a mindset, a way of thinking - a set of principles and values " (Peter Trudelle, 2013).

Kazakhstani authors have also looked at various aspects of project management. Turginbayeva et al. (2018) considered financial issues of the effectiveness of innovative projects and evaluated the competitive advantages, based on the importance of increasing the region's competitiveness for the economy (Turginbayeva et al, 2013).

Kozhakhmetova A et al. (2019) found that differences in national culture influenced project management style and that project outcomes differed, which indicated that project success depends on project management style.

Kunanbayeva et al. (2013) focus on change management in projects and analyze the challenges of implementing change in the organization.

Sansyzbayeva $\mathrm{G}$ et al. (2015) defined the role of development institutions in the implementation of state programs. According to the State Concept of Tourism Development in Kazakhstan, state support for hotel projects organized according to international standards and taking into account national peculiarities is also relevant.

In recent years, world tourism has been developing rapidly. The tourism industry's contribution to the GDP is increasing year by year.

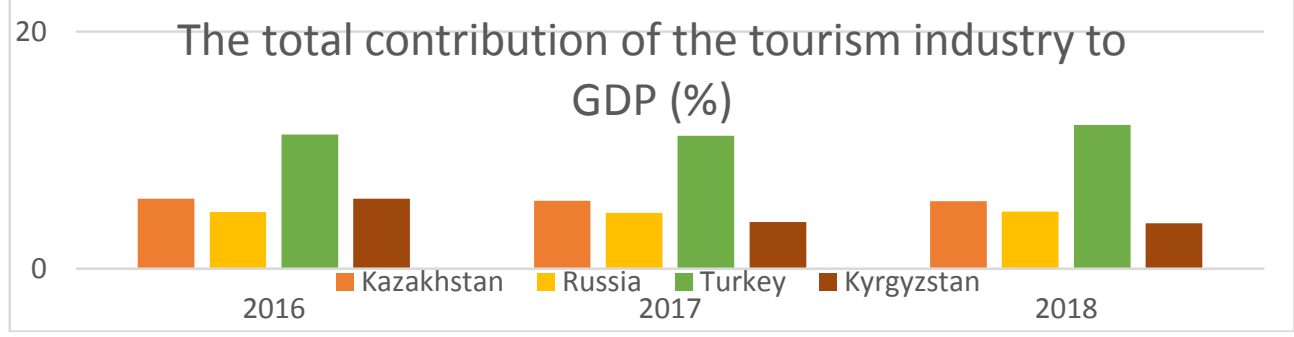

Fig 1. The total contribution of the tourism to GDP.

*Priming - Prepared by authors based on the following source https://knoema.ru/atlas/topics/

The hotel business, due to the development of the tourism industry, must also increase its competitiveness. In order to increase their competitiveness, the hotel industry companies are considering measures to restructure, optimize business volumes, introduce quality 
management programs and increase corporate culture. However, the increasing role of human capital in service does not focus on customer service. Change management also needs to be considered for effective hospitality project management. By managing change you can achieve effective project results.

\section{Results and Discussion}

Command control of the hotel project, in the right corner, on the strategic strategic project. The command is made from uninterrupted storon from divisional and professional splinters, which can be used to adapt to the new processes. Managing changes involves solving the ethical problem. The manager of the changes will load all the project sites to solve the problem, get in the process of managing the projects and create a lot of problems. The manager of the change needs to look at the change request and to find the storage rooms and other uninterested storons, as these changes can be done on the result of the project. As a result, the pre-ordered seals test projects in the hospitality business.

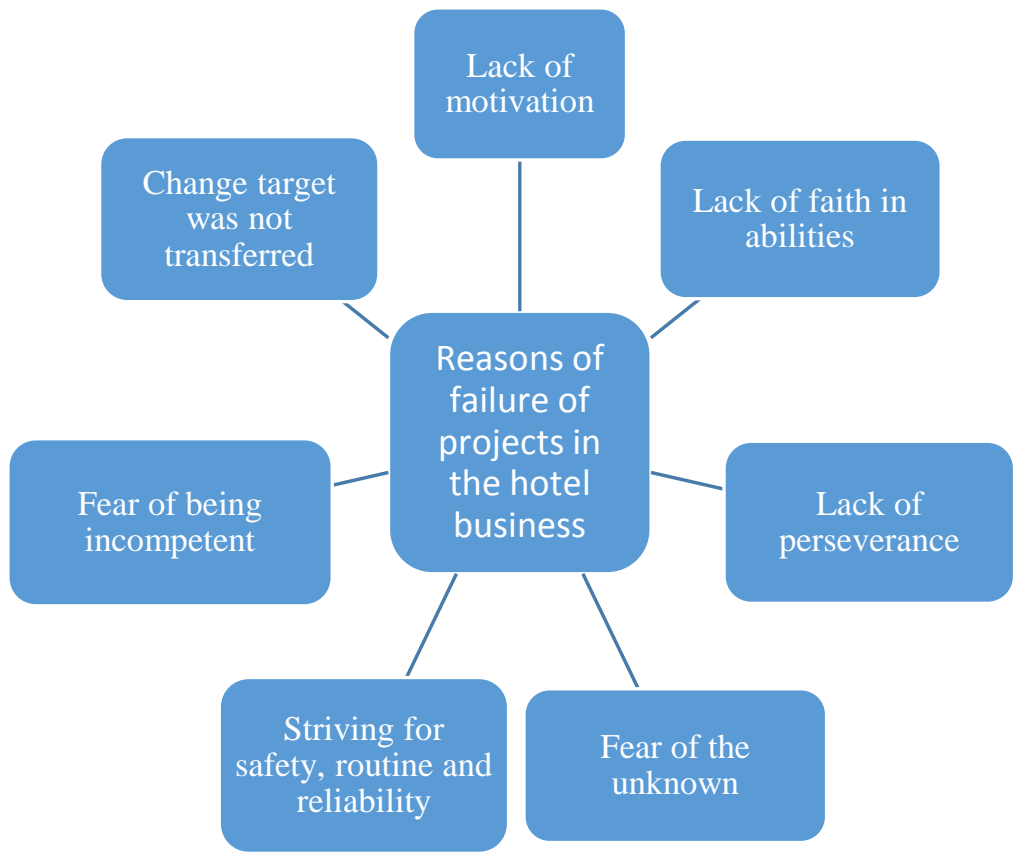

Fig 2. Reasons of failure of projects in the hotel business.

* Priming - Prepared by authors

It can be argued that successful change management is critical for any organization to survive and succeed in today's highly competitive and ever-evolving business environment.

In order to counteract intra-organizational resistance in a hotel business project, the project manager must encourage people to abandon their established patterns of behavior and ways of working. Lack of knowledge on change management in the hospitality industry leads to project delays and unsatisfactory project results. In order to avoid the resistance of project participants, it is necessary to establish a sense of urgency or necessity of the project from the very beginning. The more employees within the organization and the project team will be motivated by the successful outcome of the project and the more they know where they 
are going, the better they can concentrate on the practical implementation of the established vision.

The vision should be anchored in the minds of the hotel staff. Achieving short-term positive outcomes is critical to the long-term success of hospitality change initiatives. After the project is completed, it is important to consolidate the changes firmly received in the corporate culture. A hotel project can also be implemented without change management. However, change management increases the likelihood that the project outcome will be positive.

Change management is best done not through the delivery of a project to the customer, but through the Agile approach at all stages of project management, and only then can the causes of the above projects fail.

Project management is based on the three most important aspects of project success since its inception: project cost, timing and quality. This concept was useful for traditional projects with a strictly defined technological procedure. A strictly structured, standardized approach to project management has been applied to long term, sustained projects. However, in the late 1990's, changes began to be required due to instability and volatility in the environment. The traditional project management model based on the waterfall method does not take into account changes in the project environment, but flexible approach is not used in all projects as a tool to increase the value of the project, its competitiveness, increase its market access rate and readiness for change. That is why hybrid technology of project management has become popular.

As mankind's education grows, especially with technological advances, systems become more complex. Organizations are faced with more complex and complex conditions. One person's personal decision may affect the whole organization. The purpose of every project should be value creation, which means that the interests of all project consumers are met.

In 2001, the Agile Manifesto was adopted, meaning a method of flexible project management. In the new project management paradigm, the key categories are: speed - value - efficiency. In this paradigm, not only the timing of the project is important, but also the speed at which clients deliver valuable results for testing, first of all the simpler form of the product offered to the customer, the post-test optimization with a lower cost and lower risk, and more competitive product variants being developed. With the introduction of flexible project management methods, the product is rapidly gaining momentum in the market, and the project team is becoming more flexible with the changes.

Both traditional and flexible project management methods and mixed models are defined according to the type, purpose, value and value of the project, and the interests of the participants. Finally, traditional approaches to project management have the importance of value-for-money, followed by complexity-value-versus-complexity, and flexibility, speed, value and efficiency.

Due to the constant change of customer requirements, project managers face a lot of problems. As things change quickly, planning is difficult, traditional approaches to project management define the requirements of the master plan, and then change management to minimize the effects of changes on the project, and flexible methods of Agile project management help to solve this problem. According to many companies, this approach to project management is more effective because it involves the involvement of each and every employee in achieving the set goals, meaning the volunteerism of each of them.

The flexible method allows you to eliminate the human factor, the influence of personal relationships between team members - to preserve order and distribute responsibilities among project team members. The Agile method is designed in such a way that the contractor and the customer agree in advance on making changes during the execution of work - even after the product does not have the specified functionality at the 
initial stage, the customer will be able to comment and make adjustments starting from the first days of the project's life .

The Agile methodology is based on the following values:
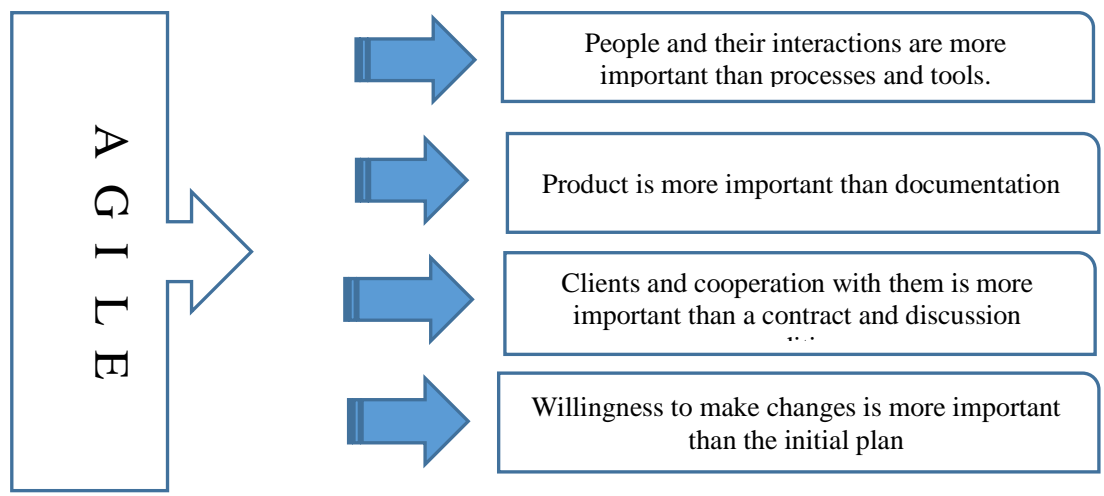

Fig 3. Agile values.

* Priming - Prepared by authors based on the following source (Kate Eby, 2016)

\section{Agile Team Roles.}

People play a key role in the development of the company; flexible principles and values are essential to the project team. The AGILE team encourages flexible actions and has the following roles:

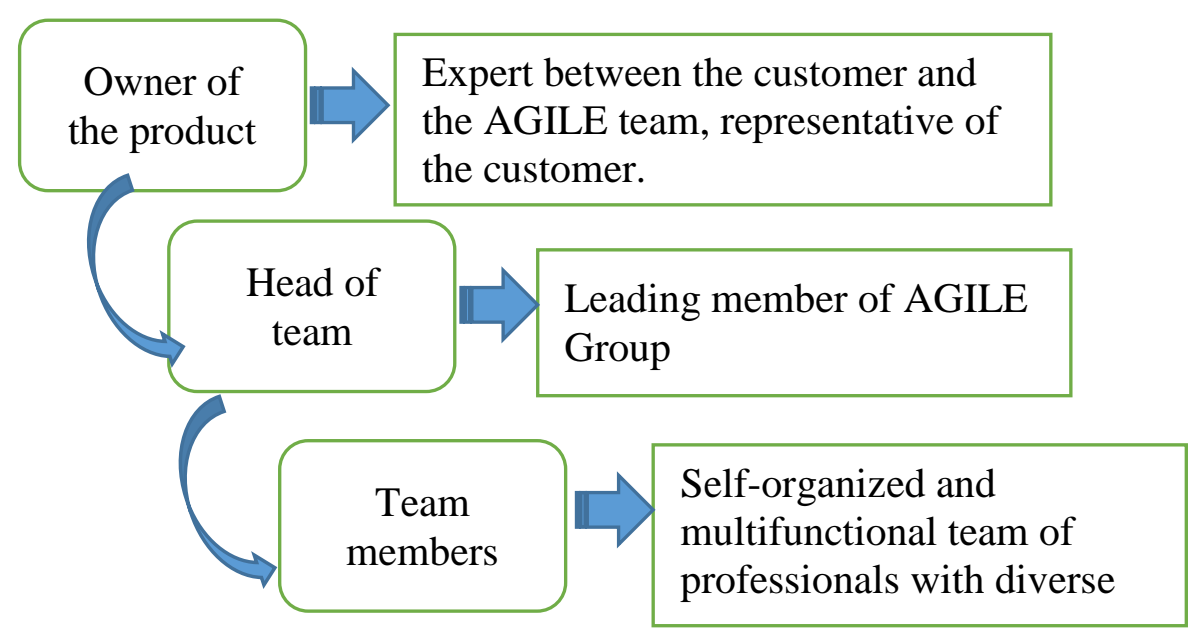

Fig 4. Agile Team Roles.

* Priming - Prepared by authors based on the following source (https://redbooth.com/blog/main-rolesagile-team)

The product owner is the customer's representative and allows daily communication with other members of the AGILE team to identify doubts regarding the client's requirements. The team leader manages and supports AGILE team members, and the team deals with external issues in order to function purposefully. Team members are self-organized because they need to be able to influence the project in various ways. In AGILE, one member of the team may play more than one role (M. Tomas 2009). 
Depending on the project, each participant can play different roles, meaning that the team does not stay in one place, but constantly changes. AGILE teamworks closely with project stakeholders and company staff.

Communicating effectively helps team members act to achieve their goals. The client is in close contact with the product owner, and the product owner discusses the client's demands with the project manager and other team members and provides explanatory work. Although the primary focus of the hospitality industry is customer-oriented, the Agile method is not in use. Hotels use the "waterfall" method. As a result, the same problems always recur. There are 3 main reasons for this:

\section{Management in the hotel business is based on operational activities.}

In many hotel business projects - object development, company upgrade or repair, the Waterfall management method is convenient. The reason is that the detailed plan is used, every step is clear and the changes are not often.

Sellers adhere to specific agreements because results are predefined. Hotel operations are recurring in nature, and despite the changing market conditions, the controls remain the same: pricing, marketing activities for clients, staff adjustments, etc. Management's focus is on efficient performance of tasks set. Business owners pay more attention to how much the project costs and how much they will profit from, over costs control over flexibility.

\section{Multidimensional organizational boundaries.}

Cross-functional teams form the basis of the Agile system. Team members interact and learn from each other, allowing for quick exchange of new information. and in the traditional system only exchanges written documents. Unfortunately, hotels are very different, revenue management, sales and marketing do not work closely, but they must be closely linked to improve RevPAR and optimize profits.

\section{Barriers to cooperation with clients.}

Agile focuses on customer service because it allows you to identify customers' opinions. The clients themselves approve of the right work and provide value. They are the staff who are the first to test and apply flexible technologies in the hotel industry, but they are free from the day-to-day operations and they have no time for new technologies.

At the same time, they are clients who directly criticize flexible project management methods, but it is more difficult to require them to provide regular feedback.

The aforementioned reasons constrain the introduction of a flexible project management system in the hotel business. However, let's try to figure out if the Agile method can be used in hotel projects by a number of criteria.

Traditional and flexible methods of project implementation include similar principles and approaches to achieving measurable results. The traditional methods of project implementation can be described as "cascading" where the requirements, expectations, duration, activities and results of the project are clearly predicted and planned. With traditional project implementation methods, the project product was not tested by the client before the project was completed, and only after the completion of the project was the product pre-screened and did not meet the client's expectations and expectations.

Flexibility can be considered as the ability of organizations to quickly identify and use market opportunities.

The flexible project management approach requires significant changes in behavior and thinking, affecting the behavior and thinking of team members in the company. When traditional management approaches are approved as planned, flexible project management (APM) will include adaptation to change, resilience to innovation, flexible products, flexibility of staff and processes, quality and reliable results.

Therefore, flexible project management is not appropriate in any environment, but only if the company applies a flexible policy to its values and strategies. 
The following table describes the traditional and flexible approaches to project implementation and the criteria for choosing methods.

Table 1. Characteristics of traditional and flexible approaches to project implementation.

\begin{tabular}{|c|c|c|}
\hline $\begin{array}{c}\text { Traditional methods of project } \\
\text { management }\end{array}$ & $\begin{array}{l}\text { Flexible project management } \\
\text { methods }\end{array}$ & $\begin{array}{c}\text { Criteria for } \\
\text { determining the } \\
\text { flexibility of the } \\
\text { project }\end{array}$ \\
\hline Based on the project & $\begin{array}{l}\text { Based on customer relationships } \\
\text { and satisfaction of their } \\
\text { requirements }\end{array}$ & Based on factors \\
\hline Based on strict regulations & $\begin{array}{l}\text { The content may change during the } \\
\text { implementation of the project, the } \\
\text { outcome of which is unknown at the } \\
\text { beginning of the project }\end{array}$ & $\begin{array}{l}\text { Strict content of the } \\
\text { project }\end{array}$ \\
\hline $\begin{array}{l}\text { The cost of making the changes is } \\
\text { very high, technologically complex }\end{array}$ & $\begin{array}{l}\text { The possibility of making changes } \\
\text { is high and the cost is low }\end{array}$ & $\begin{array}{l}\text { The complexity of the } \\
\text { changes }\end{array}$ \\
\hline $\begin{array}{l}\text { The products of the project are sold } \\
\text { exclusively to the customer }\end{array}$ & $\begin{array}{l}\text { It can be divided into blocks and the } \\
\text { product can be sold to the client }\end{array}$ & $\begin{array}{l}\text { Mechanism of sales } \\
\text { of products to the } \\
\text { customer }\end{array}$ \\
\hline $\begin{array}{l}\text { External environment factors are } \\
\text { considered stable }\end{array}$ & $\begin{array}{l}\text { The content of the project will be } \\
\text { modified taking into account the } \\
\text { variability of environmental factors }\end{array}$ & $\begin{array}{l}\text { Impact of } \\
\text { environmental factors } \\
\text { on the project }\end{array}$ \\
\hline $\begin{array}{l}\text { Changes in traditional project } \\
\text { management will be responded to, } \\
\text { but will be corrected or preventive }\end{array}$ & $\begin{array}{l}\text { Changes in flexible project } \\
\text { management are controlled by } \\
\text { adaptive actions }\end{array}$ & $\begin{array}{l}\text { The nature of the } \\
\text { change management } \\
\text { process }\end{array}$ \\
\hline $\begin{array}{l}\text { In traditional project management, } \\
\text { top-down control is performed }\end{array}$ & $\begin{array}{l}\text { Flexible project management } \\
\text { involves the creation of a self- } \\
\text { organized and cross-functional team }\end{array}$ & $\begin{array}{l}\text { Organizational } \\
\text { structure and team of } \\
\text { project management }\end{array}$ \\
\hline $\begin{array}{l}\text { Traditional project management is } \\
\text { contract-oriented }\end{array}$ & APM is client oriented & $\begin{array}{l}\text { Orientation of project } \\
\text { management } \\
\text { methodology }\end{array}$ \\
\hline $\begin{array}{l}\text { Stakeholder's opinion is clear and } \\
\text { has little influence }\end{array}$ & $\begin{array}{l}\text { Stakeholder interests may vary, } \\
\text { with high levels of influence }\end{array}$ & $\begin{array}{l}\text { Level of influence of } \\
\text { stakeholders }\end{array}$ \\
\hline
\end{tabular}

Table 1. Prepared by authors based on the following source (Özkan Murat, 2016)

Choosing the most traditional approach and flexible approach to project management in the hotel business, you can determine the best option based on the criteria in the table. Since the projects are diverse, management should be performed according to the priority categories, based on the individual elements of both methods.

\section{Conclusion}

Agile is an innovative way of organizing new products or services. At the heart of it is a simple idea: each participant in the process, each employee should re-think their tasks and common goals, and be fully integrated into the project management process chain. Any member of the group can stop the conveyor and make their rational proposal.

The managing company needs to be the first to introduce news to the company every day, and the desire for innovation has become a part of the company's corporate culture. Innovative culture is shaped by strategic goals, mission building, and meetings and discussions. 
Agile is a procedure that helps a project team manage projects easily. These procedures allow you to divide the main task into several stages, as well as provide ongoing collaboration with stakeholders. Customers describe how the end product will be used or the problem that will be solved by that product, which will help the project team to better understand the expected outcome of the project. Lastly, the project team and project stakeholders have ongoing partnerships to make sound decisions.

It is important to look for ways to use this simple approach in hotel business project management.

\section{References}

1. A Guidebook of Project \& Program Management for Enterprise Innovation (P2M), Volume I Revision 3, Project Management Association of Japan (PMAJ), October 2005

2. Bar-Yam, Yaneer Making things work : solving complex problems in a complex world. London : Knowledge Industry, 2004

3. https://knoema.ru/atlas/topics/

4. Kate Eby Comprehensive Guide to the Agile Manifesto. https://www.smartsheet.com/comprehensive-guide-values-principles-agile-manifesto. Jul 29, 2016

5. Kozhakhmetova A., Zhidebekkyzy A., Turginbayeva A., Akhmetova Z. Modelling of project success factors: A cross-cultural comparison. Economics \& Sociology, Vol. 12, No.2, 2019

6. Kunanbayeva D., Kenzhegaranova M. Resistance to Change in Organizations of the Republic of Kazakhstan: Country-Specific Reasons and Ways to Overcome it. World Applied Sciences Journal 28 (2): 223-232, 2013

7. Özkan Murat. Agile Project Management in the Travel Industry August 21, 2016

8. Peter Trudelle. What is Agile, a framework or methodology? Retrieved from www. quora . com /What - is - Agile - a - framework - or-methodology(2013)

9. Plonka, F. E. Developing a lean and agile work force. Human Factors and Ergonomics in Manufacturing \& Service Industries, 7(1), 11- 20(1997)

10. Sansyzbayeva G, Ametova Zh. The Role of "Samruk-Kazyna" Sovereign Wealth Fund in Implementation of State Programs of the Republic of Kazakhstan. Asian Social Science; Vol. 11, No. 2; 2015

11. Sara Ekberg. Are opportunities and threats enough? A development of the labels of strategic issues. Journal of Media Business Studies 07 Aug 2019

12. The 3 Main Roles in an Agile Team. https://redbooth.com/blog/main-roles-agile-team

13. Tomás, M. R. Métodos ágeis: características, pontos fortes e fracos e possibilidades de aplicação, 19 p. (2009)

14. Turginbayeva, A., Ustemorov A., Akhmetova G., Kose Zh., Imashev A., Gimranova G. Financial Aspects of an Effective Strategy for Innovative Enterprise Development. Journal of Advanced Research in Law and Economics, Volume IX, Issue 4(34), Pp 714 - 719 Summer 2018

15. Turginbayeva, A.N., Abildaev, S.T. The Issue of Quantitave Asessment Competitiveness of Regional Economy on the Example of the Republic of Kazakhstan. Actual Problems of Economics. - №8. - P. 477-485, 2013 